\title{
Students' Perception of Teachers' Bilingual Language Use in EFL Classroom
}

\author{
Desi Surayatika ${ }^{1)}$ \\ ${ }^{1)}$ Program Studi Pendidikan Bahasa Inggris, Universitas Indo Global Mandiri \\ Jl. Jend. Sudirman No. 629 KM.4 Palembang Kode Pos 30129 \\ Email : desisurayatika@yahoo.com ${ }^{1)}$
}

\begin{abstract}
Students' perception of teachers' bilingual language use was based on bilingual approach in English language learning in which the students' first language ( L1 ) is combined with the target language ( L2) being studied to be a language instruction used by the teacher to conduct an English classroom. The purpose of this research was to find out the students' perception toward the use of Bilingual language they are English and Indonesian by the teacher in EFL classroom. This research was a qualitative approach with the forty students as the sample. In collecting the data, questionnaire was used. The data was analyzed through Likert Scale in order to find out students' perception of teachers' bilingual language use in EFL classroom. Based on the result of data analysis and interpretation of the data gained from questionnaire, it indicates that students show their positive perceptions to the use of bilingual language done by the teacher as language instruction in their English classroom. Finally, the result of the research would give a contribution to the improvement of the classroom language instruction used by the teacher in an English language learning classroom particularly for teaching the students who were learning English as a foreign language (EFL).
\end{abstract}

Keyword : Bilingual, Students’ Perception, language use, EFL classroom

\begin{abstract}
ABSTRAK
Persepsi siswa tentang penggunaan dua bahasa oleh guru didasarkan pada pendekatan bilingual dalam pembelajaran bahasa Inggris di mana bahasa pertama siswa ( L1) dikombinasikan dengan bahasa target (L2) yang dipelajari menjadi pengajaran bahasa yang digunakan oleh guru untuk melaksanakan pembelajaran bahasa Inggris di kelas. Tujuan dari penelitian ini adalah untuk mengetahui persepsi siswa terhadap penggunaan dua bahasa yaitu bahasa Inggris dan bahasa Indonesia oleh guru di kelas EFL. Penelitian ini menggunakan metode kualitatif dengan empat puluh siswa sebagai sampel. Dalam mengumpulkan data, kuesioner digunakan. Data dianalisis melalui Skala Likert untuk mengetahui persepsi siswa tentang penggunaan dua bahasa oleh guru di kelas EFL. Berdasarkan hasil analisis data dan interpretasi data yang diperoleh dari kuesioner, hal ini menunjukkan bahwa siswa memiliki persepsi positif terhadap penggunaan dua bahasa yang dilakukan oleh guru sebagai bahasa pengantar di kelas bahasa Inggris.. Pada akhirnya, hasil penelitian diharapkan dapat memberikan kontribusi pada peningkatan pengajaran bahasa Inggris di kelas yang digunakan oleh guru di kelas pembelajaran bahasa Inggris terutama untuk mengajar siswa yang belajar bahasa Inggris sebagai bahasa asing ( EFL ).
\end{abstract}

Kata kunci : Dua bahasa, Persepsi Siswa, penggunaan bahasa, kelas EFL 


\section{Introduction}

English becomes one of the most spoken languages by world citizens. In Indonesia, English is utilized in several fields for example in foreign companies, educational institutions, and foreign offices. It is hard to find the use of English in daily conversation. Indonesia took different stance by putting English as its foreign language while neighbor countries such as Filipina, Singapore, and Malaysia view English as the second language. Nowadays, society starts to be aware of the significance of learning English, not necessarily because of its role in knowledge, science, and technology but more because of the role of English in economic activities and career progress. The awareness of English as an international language and as a language of science is responded with mandatory English teaching at school to varsity level. However, with the status as foreign language, English is occasionally used outside the classroom. Even during the class, instead of speaking English the Indonesia students tend to speak in Bahasa Indonesia (Indonesian Language) or their local language. Such situation directly affects the Indonesian students' English mastery. Generally speaking, the teaching of English language in Indonesia has been labeled as to be far from successful. It can be seen from the fact that after the class ended, most Indonesian students cannot use English properly in their communication. The important goal of learning English in Indonesia is to communicate with other people around the world.

Existing students' native language in an EFL classroom will influence the classroom dynamic and suggestions, because L1 provides a sense of security and validates the learners' live experiences, allowing them to express themselves (Schweers, 1999, p. 7). In addition, according to Brown (2000), teachers and educators have debated whether or not they use the students' first language (L1) in an EFL classroom. Some teachers may think that teaching foreign language to students and bringing their L1 to take a part in the learning process may be effective for them to learn the foreign language, especially for the students in the low level proficiency of English because allowing students to be close to their native speaker will help them to learn and to acquire a new language (Cook, 2001a, p. 171-172). Moreover, to be proficient in a new language acquisition, someone should have basic knowledge of the new language. As stated by Saville-Troike (2006, p. 18) that since L2 acquisition follows L1 acquisition, a major component of the initial state for L2 learning must be prior knowledge of L1. Students will acquire the L2 when they have a prior knowledge of L1 in which responsible for the transfer from L1 to L2 during second language development. That prior knowledge helps them to develop their second language acquisition and act as a tool to be proficient in that target language or second language (L2) learning process. On the other hand, in Indonesian context, there is also no regulation or education institution policy for the use of language instruction in order to conduct an English language learning (ELL). Language instruction in ELL classroom is only determined by the teachers who teach English as the learning subject. Teachers only determine the language use based on their belief or their used approach to language learning. Furthermore, in order to determine the language use for conducting their EFL classroom, teachers actually have two kinds of language instruction alternative; whether to use (1) English only or (2) English is incorporated with Indonesian language or students' first language (L1).

The use of bilingual approach in EFL classroom especially for teaching English to the students is needed to be found out. Based on the background, the objective of the research was to find out the student's perceptions toward teacher's bilingual language use in EFL classroom.

\section{A. Literature Review}

English is totally foreign language in the case of Indonesia. Reiterating, there are four types of languages that exist in Indonesia. Starting from Bahasa Indonesia as the main language which functions as the language of identification and the identity of the nation, regional language or Bahasa Daerah, variant languages whereby the mixture of regional and Bahasa Indonesia, and lastly foreign language. Language variation that exists in Indonesia seems to affect the perception of the people regarding the priority of mastering the foreign language especially English. Thus, most Indonesians, with the exclusion of some people who live in the urban areas, are bilingual. They speak Bahasa Indonesia as the national language during formal occasions, variants of the Indonesian languages and the regional language as the mother tongue. Thus, the people who lived in the big cities such as Jakarta are those who are really concern about the importance of English language as a skill that needs to be mastered in the pursuant of a better job and an increase of their status. With this in mind, some quarters tend to question the loyalty and identity of Indonesian as a whole when a foreign language is mastered. People are probably more appreciative of being able to sound more like a native speaker than like an Indonesian. They believe that sounding like a native speaker increases their status in the community as well as giving them an elevated identity. It will also build their network to the more open job prospects such as a manager, businessman and the like. However, there is much yet to be done in the development of English language teaching and learning in the Indonesian setting. In the same vein, the enhancement of the students' ability in mastering English language also depends factors such as the books used, the quality of the teachers, the students' motivation themselves, parental encouragement, surroundings and also the school curriculum. If the English language is treated to be the most essential language that every student in Indonesia must be proficient at, all of the factors mentioned must support the development of the skills in English language learning. Lauder (2008) asserts: in countries like Singapore, Malaysia and the Philippines, there is a 
national language, or languages, and alongside this, English plays an important role as the administrative and business language of the country. This situation gives people there benefits. The policy in Indonesia has never recognized English as an official or second language. While the national language is spoken today by a majority of the population, the situation is multilingual with many also speaking one or more of the local vernaculars. (p.76)

Moreover, students has different perception towards English language that is as an international language. According to Mussen (1973) defines perception as the process of how the information is acquired through the sensory receptors (e.g. eyes, ears, nose, and skin) which is transformed into a perception of what we think, see, hear, smell, taste, or touch. In addition, Kumar (2010) explains the concept of perception in perspective of philosophy, psychology, and the cognitive sciences that perception is the process of attaining awareness or understanding of sensory information. Furthermore, he also defines that perception is the process of selection, organization, and interpretation of stimuli by someone to be a coherent and meaningful picture of the world. In other words, by passing perceptual process, people can interpret their idea meaningfully based on what they see, hear, taste, smell, and touch. According to Walgito (2001), perception which is begun by the process of feeling, of measuring something which is also the process of accepting stimuli by individuals through sense organs or it is also called sensory process. Therefore, it can be concluded that perception is the process of stimuli receiving from someone through sensory receptors and producing it to become a meaningful thing either idea or picture of something. Furthermore, According to Harnad (1987), there are two aspects of perception. The first aspect is cognitive. This aspect emphasizes on understanding and making sense of things. It includes reasoning, arguments, logic and perception. Cognitive aspect can be examined by seeing the results of how emotion, experience, and intelligence contribute to the understanding and responses. Meanwhile, the second aspect is psychology aspect. Harnad (1987) also mentions that in psychology aspect, it only focuses on the relation of experience that influences stimulation, and then the result of it affects the perception itself. In addition, Handini (2014) says that those aspects have role in determining and affecting someone's perception.

In EFL classroom, the teachers sometimes teach English using first language (L1) which has some advantages and disadvantages for students in developing their English skills. The following studies show the advantages of using L1 in the classroom. Teacher's use of L1 can help students to use the limited time efficiently with productive or communicative activities (Atkinson, 1992: 351 in Miles 2004). It means the interference of using L1 by the teachers can help students to use valuable class time efficiently. For the students, teachers who teach using L1 can help them find a new word in the target language. This is in line with statement from Swain and Lapkin (1998) who state that L1 can assist in the comprehension and memorization of L2 vocabulary. Furthermore, the use of L1 in the classroom as a translation technique also can avoid misleading. This is because L1 translation is usually clear, short, and familiar, qualities that are very important in effective definitions. In addition, students also gain the benefit of the use of L1 in the classroom. They can clarify unfamiliar vocabulary and communicate grammar points especially when teacher delivered it by using L1 in the teaching process (Storch and Wigglesworth, 2003). Based on the above studies, it can be assumed that the use of L1 by the teacher creates less threatening atmosphere in English classroom. This situation also brings an advantage for both teacher and students to decrease students' language anxiety in communication. Besides, the use of L1 also encourages students to learn English. It also helps students to understand the expression used by the teacher. However, there are also several disadvantages of using L1 in the classroom based on the following studies, the use of L1 also shows some disadvantages to the English teaching process in the classroom. Fillmore (1983) explained that the students who are used to hear their teachers using L1 will tend to ignore the target language. When teacher used L1 in the learning process, the students will be accustomed to the use L1 and will wait for the translations. This situation can lead to the failure of the maximum use of English. Miles (2004) explained that the use of L1 by teachers can over simplify differences between two languages, create laziness among students and a failure to maximize English use in the classroom. Furthermore, Zacharias (2003) stated that L1 can be seen as a barrier to English exposure. This could be a main disadvantage of teaching foreign language.

Since foreign language classroom is defined as a multilingual setting and in which multilingual communication is bound to take place (Miettinen, 2009, p.6) in which it also includes bilingualism (Savilletroike, 2006, p.4), the brief discussion should be conducted for enriching the literature of the present study. Regarding to the role of L1 in an EFL classroom, there are several professionals who describe some roles of students' native language (L1) in an English learning field. According to Dujmović (2007, p. 94-95), there are seven roles of incorporating students' native language in English learning. Moreover, there are also three roles of students' native language (L1) in English as a foreign language classroom which are argued by Kelilo (2012). There are three roles of L1 in EFL classroom that argued by Kelilo (2012); it includes pedagogical role, psychological role, and socio-cultural role. In pedagogical role, it is believed that students' native language (L1) use in foreign language classroom plays pedagogical value. Actually, it creates support for students in learning English. English learners need the existence of their native language (L1) to understand the logic and organizational principles of the target language and also to help them in understanding the new language. On the other hand, it can be said that L1 becomes the prior knowledge for learning the new 
language. Moreover, in psychological role, Kelilo (2012, 27) believes that students' native language (L1) makes students feel comfortable in expressing their thoughts and feel free to do something in class. It also confirms Auerbach's (1993) statement which states that students' native language use in the foreign language classroom reduces the psychological barriers of English learning and gives significant progression (in Kelilo, 2012). Meanwhile, in socio-cultural role the use of L1 relates the atmosphere of L2 classroom with the culture of the students. Therefore, the students will learn the L2 in the authentic environment and it helps the teacher in designing L2 classroom activities. It is also believed that incorporating students' first language in L2 classroom creates socio-cultural role in which students' culture and English learning situation are linked by it. Students would be better in learning a new language if there is a link of students' culture and the target language itself. It creates learning environment exists in natural settings.

The Reasons for Students' L1 Use in EFL Classroom According to the result of some studies carried out by Atkinson (1987), Schweers (1999), and Nation (2003), based on statement of Bouangeune (2009) the result of those three researchers is due to seven reasons of the use of students' first language as a tool in language learning classroom; having communication in students' first language in a L2 classroom is more natural, especially for those who have similar native language, incorporating students' L1 in L2 classroom is more effective and easier for both students and teacher in communication during the class, the existence of students' native language in L2 classroom helps the teacher in managing the task and helps the teacher to move the task includes establishing joint understanding of text, the use of students' native language (L1) will help teacher to facilitate classroom activities, especially in delivering a complex task, it also helps students to focus their attention to the vocabularies and grammatical items of the target language, students' native language creates a foundation for the learners especially in target language structures, and it is believed that L1 use in L2 classroom provides a sense of security, validates students' live experience, and allows them in expressing themselves. Moreover, Tsukamoto (2011) also argues that there are three reasons for bilingual approach: to maintain a comfortable classroom atmosphere, to promote the students' comprehension and to use the class-time efficiently. In line with that statement, Polio and Duff (1994) also state that the use of L1 is useful for creating a relaxing atmosphere in the classroom. Besides, in the way of promoting student' comprehension of language, Auerbach (cited in Tsukamoto, 2011) in her research has found that the use of L1 had a successful effect in lowering the students' anxiety levels and other affective barriers for students. Finally, Atkinson (1987) proposes that the most frequent justification given by teachers for L1 use is that time saved by communicating in the mother tongue can be used for more productive activities.
In this research, teaching and learning activity focused on bilingual language use by the teachers in teaching English. Bilingual in this study refers to the use of students' first language (L1) in learning target language which is in this case learning English. Hence, teacher's bilingual language use in this study is defined as two languages of classroom instruction used by the teacher in teaching English, or it is also meant incorporating the students' native language (L1) in English language learning (ELL) classroom as a learning tool (Dujmovic, 2007). In this study, it is the application of Indonesian (L1) and English (L2) in teaching English to the beginning level of students. According to Mcgroarty (in Celce-Murcia, 2005, p. 345) in her material which is entitled 'Bilingual Approach to Language Learning', she clearly explains what the bilingual approach is. It is noted that bilingual approach is applied in the similar group of students where two languages (or more) are used as a language instruction in learning a language subject. In other words, bilingual approach applies two or more languages classroom instruction as media in learning second language or foreign language in which it is applied in a class where the students have similar language

\section{B. Methodology}

In this research, a qualitative approach was applied in order to meet the objective of the research. Questionnaire was used as the instrument in order to gain the data information about participants' background, participants' view regarding classroom language used by the teacher, students' perception about teacher's bilingual language use in English classroom, and the benefits of teacher's bilingual language use for students in learning English. Furthermore, the data from all instruments were transcribed, analyzed, and interpreted to gather and enrich the data result for the research findings in a qualitative way.

\section{Population and Sample}

Population is a larger group to which one hopes to apply the results (Fraenkel, Wallen and Hyun (2010, p. 91-92). The population of this study involved the students at University of Indo Global Mandiri. Then, there were forty students is as the subject in this research. The sample was the students of English Study Program at University of Indo Global Mandiri Palembang who were taught by a teacher who uses bilingual approach or two languages of classroom instruction (Indonesian and English) as a classroom language instruction.

\section{Instrument}

In obtaining the data, this research used questionnaire which was given to the students. The students were given a questionnaire related to the use of teacher's bilingual language use in English classroom. In order to avoid misunderstanding of the respondents in understanding the aims of each question, before the questionnaire administered to the respondents, the questionnaire was adopted and translated into Indonesian language. 
There were ten statements in the questionnaire which were used to categorize the students' perception of teacher's bilingual language use in the English classroom. Students answered the list of statements by giving cross $(\mathrm{X})$ whether they agree or disagree with each statement. The data from questionnaire were used to know students' perception of teacher's bilingual language use in an English classroom and classified whether students' perceptions of it was positive or negative. The data from the questionnaire were analyzed by using Likert scale in order to find out students' perception of teacher's bilingual language use. Then, the data from the questionnaire were counted and classified whether the students agree or disagree about teacher's bilingual language use in an English classroom. It was categorized into positive and negative perception in order to gain information about students' perception of teacher's bilingual language use in an English classroom for students in learning English. In order to answer the first question of this study which is about students' perception of bilingual teacher language use in an English classroom, the data gained from questionnaire were analyzed and explored. According to Gal, Gall, and Bort (2003), Likert scale is defined as "a measurement which asks individual to check their level of agreement with various statements about an attitude object i.e. strongly agree, agree, uncertain, disagree, and strongly disagree". This study used the data which were categorized into strongly agree, agree, disagree, and strongly disagree. Uncertain statement was not used in this study; this was aimed to avoid uncertain data from the students. Then, the data were counted and classified whether the students agree or disagree about the teacher's bilingual language use in an English classroom. Finally, the result of this instrument was categorized into positive and negative perception. Furthermore, in calculating the data using Likert scale, each student's answer would be classified into percentage data. Then, it used to present the data from questionnaire to help the researcher classify and interpret it easily. Based on Ockert (2005), there are several steps in calculating data using Likert scale; those are scoring the questionnaire, finding out the score of the answer, calculating the central tendency of the answer, and classifying the average percentage.

3. Procedures

The participants including the students were given the questionnaire at the end of the course (seven weeks later). The students were given the questionnaire in their classroom, and they returned it to me when they were finished. They were given approximately 15 minutes of the class time to complete the questionnaire. During these 15 minutes, teachers were asked to leave the classroom. The students were asked to write only their ID numbers on the questionnaire. There was a privacy policy that their teachers would not see their answers, and their answers would not affect their grades at all. The students were allowed to ask and answer the openended questions in their first language since their English might not be fully developed enough to express their thoughts. Their answers were later translated into English by a bilingual speaker of English and Indonesia.

\section{Findings and Interpretations}

\section{A. The Findings of Study}

Based on the research question which was aimed to find out students' perceptions toward teacher's bilingual language use in EFL classroom, this study revealed that students showed their positive perception to the use of bilingual teacher's language as language instruction in their English classroom. This finding had been supported by the analysis of the data gained from the questionnaire. The data from questionnaire had shown that from eight statements in the questionnaire, the students gave their agreement positively to all the statements in the questionnaire. It could be revealed that students had strong positive perception to teacher's bilingual language use in their English classroom. It was proven by the amount of central tendency of this statement which reached $83 \%$ and it indicated that they had very strong perception on the use of bilingual language used by the teacher in English classroom. In addition, it was also supported by the total vote of the students, in which no one of students answered disagree or strongly disagree to the first statement (62\% agreed and 38\% strongly agreed). Moreover, the data from the questionnaire also showed that students gave their strong positive perception toward the use of bilingual teacher's language instruction in their English classroom. It was shown by the statements in the questionnaire responded by the students. Those statements reached more than $75 \%$ of central tendencies which indicated that students had strong and positive perception toward those statements which stated about the advantages of teacher's bilingual language use in English classroom. Even on another side, the last statement reached the central tendency in the level of enough, it was $42 \%$. Actually, it was a good result and it could be classified as a supporting statement for the first statement which indicated that students really had positive perception toward teacher's bilingual language use, because the last statement stated about the lack of bilingual approach. Regarding this statement, students mostly responded disagree with the statement. It could be concluded that more than a half of students which was 35 students were strongly agree that the use of bilingual language by their teacher was not making them confused in understanding English lesson. Therefore, the researcher concluded that the students had positive perception toward teacher's bilingual language use in English classroom. Furthermore, in finding the answer of the first research question, the findings from the questionnaire were also supported by the data from interview. Based on the data gained from some questions in the interview, it showed that students' responses to the use of bilingual language by the teacher were positive with stating that bilingual language was necessary to be applied in English classroom. The reasons for their agreements of their perception to the use of bilingual 
language were varied based on what they felt, thought, and experienced.

\section{B. Interpretations}

The findings confirm that, when allowed, students show a desire to engage in off-topic conversation and playful talk in the language class. The classroom in this research indicated that the seldom engaged in unplanned language use and, did not really see its advantages. In the efforts to cover the planned material the students often felt pressed for time, which did not allow them to lose precious minutes to spontaneous classroom communication. As a result, and except for this one student, off-topic conversations were often marginalized by quickly bringing them to a close. Interestingly, however, what transpires from the classroom is that learners have the capacity for creative language use, it means English was used by some students. This and other instances in our data show that creativity is a pervasive feature of more routine uses of language, not only outside but inside the language classroom as well. When allowed, learners displayed the kind of everyday creativity that characterizes language use in general. It must be noted, however, that everyday creativity as normal practice is usually seen in relation to L1 in the literature. What is remarkable about the language play in our study, therefore, is the fact that students engaged in everyday creativity and came up with expressions in the foreign language. In so doing, they demonstrated heightened metalinguistic awareness of what is possible in the target language as well as the ability to express their identity. Playful, spontaneous language use in the lessons often included the combination of creativity. It seems that the blend of play allows students to take risks and function outside the traditional confines of classroom communication. Language use thus creates learner-centered authenticity where learners use the target language in and on their own terms, and communicate very much like they would in situations outside the language class.

\section{Conclusions}

\section{A. Conclusions}

The explanation of conclusion below is based on the results of the analysis of the data collected from the questionnaire which had been conducted for gaining the data for this study. Besides, the findings and the discussions had also been done to draw the conclusions for this study. The implementation of teacher's bilingual language use was based on bilingual approach in English language learning in which the students' first language (L1) is combined with the target language (L2) being studied to be a language instruction used by the teacher to conduct an English classroom. In conclusion, it can be concluded that students had strong positive perception to teacher's bilingual language use in their English classroom. It was proven by the amount of central tendency of this statement that indicated they had very strong perception on the use of bilingual language used by the teacher in English classroom.

\section{B. Suggestions}

It is recommended to English teachers in EFL field to use both English and students' first language (Indonesian) wisely and it is based on the best proportion for each language use in classroom, because every class in schools has its own needs which are considered based on the needs of students in each class. It is also important to know that even teacher's bilingual language use is helpful for students in learning English; it also can trigger students' perplexity of the language use itself. The students will be confused when the teacher explains something too fast and when the situation of the class is uncomfortable. Hence, that condition can trigger the lack of students' attention which leads them to be confused to what the teacher explains and says about. Thus, the teachers have to check the students in every situation whether or not they are confused to teacher's language use.

\section{References}

Atkinson, D. 1987. The mother tongue in the classroom - a neglected resource?. ELT Journal, 44 (4), 241247.

Bouangeune, S. 2009. Using L1 in teaching vocabulary to low English proficiency level students: A case study at the National University Laos. English Language Teaching, 3 (2).

Brown, H. D. 2000. Teaching by principles an interactive approach to language pedagogy. San Francisco, CA: Longman.

Celce-Murcia, M. 2005. Teaching English as a second or foreign language. Newbury House Publication.

Cook, V. 2001. Using the first language in the classroom, The Canadian Modern Language Review, 57 (3), 402-423.

Dujmović, M. 2007. The use of Croatian in the EFL classroom. Metodicki obzori, 2 (1), 91-100.

Fillmore, L. 1983. The language learner as an individual: Implication of research on individual differencesfor the ESL teacher. TESOL '82: Pacific Perspectives on Language Learning and Teaching.

Fraenkel, J. R., Wallen, N. E., \& Hyun, H.H. 2010. How to design and evaluate research in education $\left(8^{\text {th }}\right.$ ed). New York, NY: McGraw-Hill.

Gal, D.M., Gall, P.J., \& Bort, R. 2003. Educational research on introduction. Essex: Pearson Education, Inc.

Handini, A. S. 2014. Students' perception on the use of English as a medium of instruction. (Research Paper). Faculty of Language and Arts Education, Indonesia University of Education, Bandung.

Harnard, S. 1987. Psychophysical and cognitive aspects of categorical perception: A critical overview. [Online]. Retrieved from http://cogprints.org/1571/.

Kelilo, J. A. 2012. Exploring the use of first language in 'English focus' EFL classroom: Focus on Jimma 
teachers' college. Postgraduate School, JIMMA University.

Kumar, R. 2010. Perception. [Online]. Retrieved from http://www.scribd.com/doc/25022 575/TheConcept-ofPerception\#scribd.

Launder, A. The Status and Function of English in Indonesia: A Review of Key Factors. Retrieved from http://idci.dikti.go.id/pdf/Jurnal/Jurnal Makara Seri Sosial Humaniora/Vol 12

Miettinen, E. 2009. As much English as possible: A study on two secondary school English teachers' language use and the motives behind their language choices. [Online]. Retrieved from https://jyx.jyu.fi/dspace/bitstream/ handle/123456789/20274/miettin en_elisa.pdf?sequence $=1$.

Miles, R. 2004. Evaluating the use of L1 in the English Language Classroom: a case study in Japan University. Novitas Royal Youth and Language Journal 4, 64 - 95.

Mussen, P. 1973. Psychology: An introduction. Toronto: D.C Health and Company.

Ockert, D. 2005. Substantive scale verification: A likert scale analysis and critique of university student pedagogical activity preferences. JALT Hokkaido Journal, 9, 48-64.

Saville-Troike, M. 2006. Introducing second language acquisition. Cambridge, UK: Cambridge University Press.

Schweers, W. Jr. 1999. Using L1 in the L2 classroom. English Teaching Forum, 37 (2), 6-13.

Storch, N., \& Wigglesworth, G. (2003). Is There a Role for the Use of the L1 in an L2 Setting? . TESOL Quarterly, 37 (4), 760-770.

Tsukamoto, M. 2011. Students' perception of teachers' language use in an EFL classroom. [Online]. Retrieved from www.wilmina.ac.jp/ojc/edu/kiyo_ 2011/kiyo_08_PDF/d2011_08.pdf

Swain, M., \& Lapkin, S. 1998. Interaction and second language learning: Two adolescent French immersion students working together. Modern Language Journal 82, 320 - 337.

Walgito, B. 2001. Pengantar psikologi umum (5th edition). Yogyakarta: Penerbit ANDI

Zacharias, N. 2003. Teachers' beliefs about the use of the students' mother tongue: a survey of Tertiary English Teachers in Indonesia. EA Jou Journal, p.44. 